\title{
Long range movements by individuals as a vehicle for range expansion in Calopteryx splendens (Odonata: Zygoptera)
}

\author{
Louise WARD and Peter MILL*
}

Faculty of Biological Sciences, L.C. Miall Building, University of Leeds, Leeds, LS2 9JT, UK; e-mail: p.j.mill@leeds.ac.uk

Key words. Zygoptera, Calopteryx splendens, dispersal, migratory movements, non-migratory movements, range expansion, territoriality

\begin{abstract}
Flight activity in zygopterans is generally restricted to short-range movements associated with foraging, reproductive activity and escape. Indeed, previous studies have suggested that Calopteryx species, including C. splendens, are relatively sedentary species, with a low tendency for long distance movements.

2. Recent observations suggest that $C$. splendens is expanding its northern range in the UK; in the northeast the species is now well established in Northumberland and, in the northwest, has recently spread into south-west Scotland. The current study aimed to investigate the mobility and dispersal tendency of $C$. splendens in a well-established breeding population in NE England.

3. A mark-release-recapture study was carried out on a population of $C$. splendens along a section of the River Wharfe, West Yorkshire, UK. 831 adult $C$. splendens were marked uniquely for individual identification in order to monitor the day-to-day, and overall, distance and direction of movement for each individual. Of these 381 were recaptured at least once.

4. The majority of males $(85 \%)$ and females $(88 \%)$ moved a distance of $100 \mathrm{~m}$ or less and only five of the recaptured individuals $(1.3 \%)$ moved a minimum distance in excess of $500 \mathrm{~m}$. Although the median distance moved by males was greater than that for females, this was not significant. In addition, there was no significant difference in the number of either males or females moving upstream as opposed to downstream.

5. The results are compared with those from other studies on calopterygid movement. Although most individual C. splendens stay within a suggested home range of approximately $300 \mathrm{~m}$, clearly individuals have the potential to cover relatively long distances, and it is these latter movements that play a fundamental role in increasing the range of the species.
\end{abstract}

\section{INTRODUCTION}

Insect movement has been classified into two main types (Danthanarayana, 1986): (1) non-migratory movements involving flights within the habitat or home range. These flights include activities such as foraging, mating, oviposition and movements to and from roosting sites, and (2) migratory movements, which facilitate the colonisation of new habitats and recolonisation of old habitats. These are movements across the wider landscape.

All species exhibit a tendency to move as a means of predator avoidance, food and mate searching, and habitat selection. The distance and duration of movement can vary in relation to the physical condition, age and sex of an individual and in response to environmental factors (Rudd \& McEvoy, 1996) such as resource availability, interaction with conspecifics, and physical barriers within the environment (Schutte et al., 1997).

For most odonates, spatial displacement by flight is largely confined to trivial flights (Johnson, 1969) involving relatively brief, short-range, appetitive movements associated with immediate goals such as escape, foraging or reproduction (Corbet, 1999). Mature adults tend to make only short daily movements to nocturnal roosting sites, unless displaced by a storm (Mitchell, 1962) or as a result of territorial disputes (Switzer, 1997a, b).

\footnotetext{
* Corresponding author.
}

For species in which the male exhibits territoriality, aggressive behaviour of unpaired males spaces them out along the river margins where they intercept females. In this way interference of copulation and oviposition is reduced, and sperm competition lessened. In areas of high quality oviposition sites, frequent territorial interactions can result in dispersal to previously uninhabited areas (Corbet, 1980). Thus, for Calopteryx splendens (Harris), and other species that exhibit territoriality, the majority of small-scale movements are directly related to selection of suitable habitat for territory (and territory defence) and courtship.

For many species of animal only a small proportion of a resident population migrates, and that proportion may change with different environmental cues (Rankin \& Burchsted, 1992). Previous studies have suggested that Calopteryx species, including C. splendens, are relatively sedentary species, with a low tendency for long distance movements (Zahner, 1960; Waage, 1972; Stettmer, 1996; Schutte et al., 1997). More recently, however, there are indications that $C$. splendens is expanding its northern range in the UK (Ward \& Mill, 2004). The species is now well established in Northumberland (Jeffries et al., 2005) and has recently been recorded in south-west Scotland (Mearns \& Mearns, 2005), there being no previous observations in Scotland. The current study aimed to investi- 
gate the mobility and dispersal tendency of $C$. splendens in a well-established breeding population in NE England.

\section{MATERIAL AND METHODS}

The study was conducted over a 28 day period from $24^{\text {th }}$ June to $21^{\text {st }}$ July 2000 , along a $1.5 \mathrm{~km}$ stretch of the River Wharfe at Newton Kyme, West Yorkshire, England $\left(53^{\circ} 54^{\prime} 5^{\prime \prime} \mathrm{N}\right.$, $1^{\circ} 16^{\prime} 57^{\prime \prime} \mathrm{W}$; British National Grid Reference SE245455). The study area was divided into 20 continuous stretches of $75 \mathrm{~m}$ along the riverbank. Each one of the 20 areas of riverbank was assigned a specific letter, for ease of identifying location when recording marked insects. Wooden marker posts were placed every $10 \mathrm{~m}$ along the length of the riverbank for reference when recording the location of all captured and recaptured damselflies.

Adult C. splendens were captured on 18 out of the 28 days; the time between searches varying from 1 to 3 days according to weather conditions. The sampling period reflected the activity of the damselflies, and was carried out between the hours of 0900 and 1600 (GMT). An insect sweep net was used to capture adult $C$. splendens, which were uniquely marked on the left forewing using a fine indelible pen. On each sampling occasion, individuals without a mark were captured and marked accordingly. Upon initial capture, the sex of the individual and the assigned unique identification number were recorded. On all initial and subsequent recaptures, the location to the nearest metre was estimated. All individuals were released at, or close to, the point of capture. When possible, "recaptures" were made with the use of binoculars to avoid repeated, unnecessary handling of individuals.

The distance and direction of movement were recorded for each individual on each day of recapture. This gave both the total distances moved, and the overall direction of movement.

\section{RESULTS}

831 individuals (403 males and 428 females) were marked, 381 (203 males and 178 females) of which were subsequently recaptured. Of these, approximately half were recaptured only once ( $52 \%$ males and $62 \%$ females), with a progressive decrease in the number of multiple recaptures.

\section{Overall movement}

The number of recaptures would be affected by mortality and permanent emigration and the recorded distances were considered to be minimum distances moved. Considering those individuals recaptured at least once, relatively few (15\% males and $12 \%$ females) moved distances of over $100 \mathrm{~m}$ (Fig. 1A) and only five $(1.3 \%)$ moved over $500 \mathrm{~m}$. Three of the latter were males, one of which moved at least $738 \mathrm{~m}$; the furthest recorded distance moved by a female was $556 \mathrm{~m}$. It is quite possible that some individuals moved greater distances. However, any individual that moved beyond the confines of the study area would clearly not be recorded.

The majority of males $(85 \%)$ and females $(88 \%)$ moved a distance of $100 \mathrm{~m}$ or less (Fig. 1A). Furthermore, $70 \%$ of males and $74 \%$ of females did not exceed movement distances of $50 \mathrm{~m}$ (Fig. 1B), and $24 \%$ of males and $26 \%$ of females did not move any further than $5 \mathrm{~m}$ from the area of their initial capture (Fig. 1C); indeed a small proportion of the population, $4 \%$ each of the males and
TABLE 1. Distance moved $(\mathrm{m})$ between June $24^{\text {th }}$ and July $21^{\text {st }}$ 2000 by adult $C$. splendens, at Newton Kyme on the River Wharfe.

\begin{tabular}{lcccc}
\hline Sex & $\mathrm{n}$ & $\begin{array}{c}\text { Median } \\
\text { distance }(\mathrm{m})\end{array}$ & St. deviation & Range $(\mathrm{m})$ \\
\hline Males & 203 & 21 & 105.44 & $0-738$ \\
Females & 178 & 18 & 86.17 & $0-556$ \\
\hline
\end{tabular}

females, did not move at all between consecutive sampling occasions (Fig. 1C).

On average males moved a minimum distance of 1.17 $\mathrm{m} /$ day; females a minimum distance of $1.00 \mathrm{~m} / \mathrm{day}$. The median distance moved by males was greater than that for females (Table 1), but this was not significant (MannWhitney $U=16246.5, P=0.40)$.

It should be noted that the distances given are linear distances along the river, which had a considerable meander. It is possible that some individuals crossed the intervening meadow to reach their destination but most individuals moved small distances from day to day, which is commensurate with following the course of the river. Furthermore, few individuals were seen over the meadow away from the vicinity of the river.

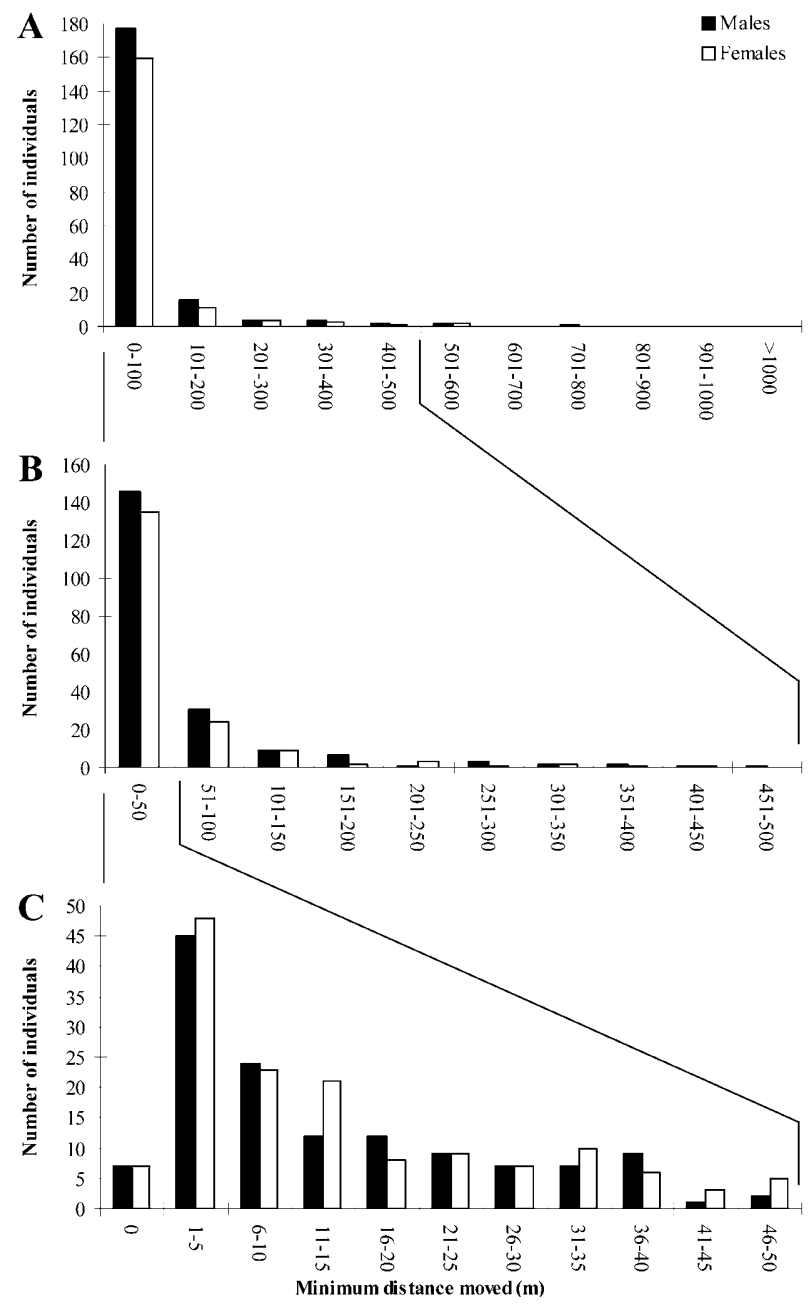

Fig. 1. Minimum distances moved $(\mathrm{m})$ by adult male and female $C$. splendens, when distances are measured at (A) $100 \mathrm{~m}$, (B) $50 \mathrm{~m}$, and (C) $5 \mathrm{~m}$ intervals. 


\section{Movement patterns}

There was no significant difference in the number of males $\left(\mathrm{Chi}^{2}=0.57\right.$, d.f. $\left.=1, P=0.39\right)$ or the number of females $\left(\mathrm{Chi}^{2}=0.23\right.$, d.f. $\left.=1, P=0.55\right)$ moving upstream as opposed to downstream and this also applied to the subset of those that moved longer distances. Furthermore, of the 203 males and 178 females which were recaptured at least once, $58 \%$ of the males and $61 \%$ of the females were captured within $10 \mathrm{~m}$ of the previous point of capture and were assumed to show no inclination to move in either direction.

Four distinct movement patterns were identified from those individuals (43 males and 37 females) that were recaptured at least three times. Of these animals, 35\% of males and $38 \%$ of females remained within $10 \mathrm{~m}$ of their initial point of capture (IPC). A return to within $10 \mathrm{~m}$ of the IPC, following movements of between $20 \mathrm{~m}$ to $80 \mathrm{~m}$ away, was observed in $9 \%$ of the males and $11 \%$ of the females, whilst $22 \%$ of males and $24 \%$ of females exhibited a movement away from the IPC, then settled in a new area. These movements were between $20 \mathrm{~m}$ to $100 \mathrm{~m}$ away from the IPC, although one male flew $361 \mathrm{~m}$ before settling in a new area. Of those individuals that showed progressive movement away from the IPC, 34\% of males and $27 \%$ of females exhibited this pattern of movement. Distances covered were between $40 \mathrm{~m}$ and $600 \mathrm{~m}$.

\section{DISCUSSION}

Over the four week period of the current study $72 \%$ of individual $C$. splendens moved less than $50 \mathrm{~m}$, and $87 \%$ less than $100 \mathrm{~m}$, from their release site. Fuhrmann (1990) recorded $70 \%$ less than $30 \mathrm{~m}$ and $90 \%$ less than $200 \mathrm{~m}$; Stettmer (1996) found that $86 \%$ dispersed less than $150 \mathrm{~m}$ and Schutte et al. (1997) 58\% less than $100 \mathrm{~m}$. Zahner (1960) found that most C. splendens and C. virgo individuals moved between $10 \mathrm{~m}$ to $200 \mathrm{~m}$, with only $3 \%$ moving distances greater than $400 \mathrm{~m}$. C. maculata shows a similar movement pattern (Waage, 1972). At the other extreme, in the current study, only $1.3 \%$ were found to move distances greater than $500 \mathrm{~m}$ with the furthest recorded distances being $738 \mathrm{~m}$ for males and $556 \mathrm{~m}$ for females. In a comparable study Schutte et al. (1997) found $2.2 \%$ exceeding a distance of $1000 \mathrm{~m}$ and recorded a maximum of $1725 \mathrm{~m}$ for males and $1475 \mathrm{~m}$ for females but their study area extended $2000 \mathrm{~m}$ compared with the $1500 \mathrm{~m}$ of the current study. Stettmer (1996) recorded $7.7 \%$ exceeding $300 \mathrm{~m}$. Conrad \& Herman (1990) found that female Calopteryx aequabilis were the more mobile, the males moving very little after establishing a territory. Waage (1972) found that, although females of Calopteryx maculata "were significantly more mobile than males, as expressed by their median movement", "the mean distance moved by males was greater than that for females, reflecting a small number of extreme movements by some males".

For species that exhibit territoriality, it may be expected that increased population densities would initiate increased migration, especially by males some of whom may have to move considerable distances before locating a suitable vacant territory, whereas only a proportion of the females will be at water at any one time (e.g. Bennett \& Mill, 1995). Females do not compete for territory sites (Waage, 1972) and would not normally "have to move out of an area containing numerous oviposition sites to acquire mates or places to oviposit" (Waage, 1972). However, in Pyrrhosoma nymphula, Bennett \& Mill (1995) found that females tended to move greater distances than males and suggested that this may be because males tended to return to the same area each day whereas females have a greater opportunity to wander as they do not visit water every day.

Of the individuals that conformed to one of the movement patterns described in the current study, the majority of males and females tended to remain within a few metres of their initial point of capture. Switzer (1997a, b) found that movement in the territorial damselfly, Perithemis tenera, was controlled by site fidelity, individuals returning to, or remaining at, a previously occupied location where breeding success was high; most moves occurring within a day were the result of territory evictions by other males. However, an increase in population density may reduce the number of territory holding males rather than increase dispersal rates. Thus Zahner (1960) reported the occurrence of non-territorial $C$. splendens at population densities between 30 and 60 males per $10 \mathrm{~m}$ of bank. A similar situation occurs in C. virgo (Pajunen, 1966), $C$. maculata (Waage, 1972) and Pyrrhosoma nymphula (P. Mill, pers. obs.). In the current study, the highest male density recorded in any one area was 35 per $10 \mathrm{~m}$ of river bank (Ward \& Mill, 2005). An increase in the numbers of non-territorial males and decreases in territory size and territorial stability have been correlated with an increase in population density in C. splendens and C. virgo (Zahner, 1960). Michiels \& Dhondt (1991) found that escape flights by male Sympetrum danae occurred more often at lower densities than at higher densities, thus suggesting that if the likelihood of encountering a conspecific is low, an individual male will move away from the current site. Similarly, Zahner (1960) found that the attachment of $C$. splendens to a certain territory was reduced in the absence of conspecifics.

For both sexes, few individuals returned to the location of their initial capture, once they had exhibited direct movement away from the area. Consideration of the possible reasons for migration from an area may help to explain this pattern of movement. A habitat may be rendered unsuitable for some individuals for a variety of reasons. Although increased population density is tolerated by the population through behavioural changes (Waage, 1972), serious over-crowding would undoubtedly result in decreased relative resource availability, and thus increased migration. Additionally, disturbance as a result of anthropogenic influence, such as anglers disturbing bank-side vegetation (L. Ward, pers. obs.) and cattle disturbance (Schutte et al., 1997; Ward \& Mill, 2005) also incite increased movement. Thus, it is understandable that movement away from an unsuitable habitat would rarely result in a return to the same location. The long distance 
movement of a few individuals from a population can ultimately lead to the colonisation of previously unoccupied areas (Kiauta, 1963; Stettmer, 1996). Thus, C. splendens has the potential to cover relatively long distances, and it is these movements by a small number of individuals that play a fundamental role in increasing the range of a species.

The current study failed to reveal any significant bias in movements upstream as opposed to downstream, for males or females. Similarly, Garrison (1978) found that stream flow had no deterministic effect on the movements of adult Enallagma cyathigerum and Argia vivida. Schutte et al. (1997) found that of 17 C. splendens individuals that moved more than $1000 \mathrm{~m}, 11$ flew upstream and 6 flew downstream. However, a $\mathrm{Chi}^{2}$ test performed on their data revealed that this was not significant $\left(\mathrm{Chi}^{2}=\right.$ 0.94 , d.f. $=1, P=0.23$ ). Whilst the aerial stages of many aquatic insects exhibit flight directed upstream (Allan, 1995), these are most notably species from invertebrate orders that largely compose the "drift" fauna, namely the Ephemeroptera, Plecoptera and Trichoptera (Madsen et al., 1973; Svensson, 1974; Müller, 1982; Peckarsky et al., 2000). Odonates are not significant components of the larval drift fauna (D. Dudgeon, pers. comm.); thus upstream movement of ovipositing females is probably not necessary as a compensatory colonisation mechanism. However, Higashi \& Ueda (1982) noted that tenerals of Calopteryx cornelia had a tendency to move upstream. Also Beukema (2002) observed upstream biased movement in a population of Calopteryx haemorrhoidalis on a small stream in north-eastern Spain. Emergence was reported only from the lower reaches of the stream, and was explained by larval drift due to strong currents regularly depleting the upper section of the stream. Larval $C$. splendens are known to be swept downstream at flow rates of $0.77 \mathrm{~m} \mathrm{~s}^{-1}$ or more (Dorier \& Vaillant, 1954). Thus for Odonata, "accidental" larval drift probably occurs as a result of dislodgement, as opposed to the active drifting shown by ephemeropteran and trichopteran larvae.

ACKNOWLEDGEMENTS. L.Ward was supported by the John Henry Garner Fellowship, University of Leeds.

\section{REFERENCES}

Allan D.J. 1995: Stream Ecology: Structure and Function of Running Waters. Chapman \& Hall, London, 388 pp.

Bennett S. \& Mill P.J. 1995: Pre- and post-maturation survival in adults of the damselfly Pyrrhosoma nymphula (Zygoptera: Coenagrionidae). J. Zool. (London) 235: 559-575.

Beukema J.J. 2002: Changing distribution patterns along a stream in adults of Calopteryx haemorrhoidalis (Odonata: Calopterygidae): a case of larval-drift compensation? Int. J. Odonatol. 5: 1-14.

ConRad K.F. \& Herman T.B. 1990: Seasonal dynamics, movements and the effects of experimentally increased female densities on a population of imaginal Calopteryx aequabilis (Odonata: Calopterygidae). Ecol. Entomol. 15: 119-129.

Corbet P.S. 1980: Biology of Odonata. Annu. Rev. Entomol. 25: 189-217.

CoRbet P.S. 1999: Dragonflies-Behaviour and Ecology of Odonata. Harley Books, Essex, UK, 829 pp.
Danthanarayana W. 1986: Insect Flight-Dispersal and Migration. Springer Verlag, Berlin, $289 \mathrm{pp}$.

Dorier A. \& VAILlant F. 1954: Observations et expériences relatives à la resistance au courant de divers invertébrés aquatiques. Trav. Lab. Hydrobiol. Pisic. Univ. Grenoble 45: 9-31.

FuHrmanN G. 1990: Zum Verhalten von Prachtlibellen gegenüber anthropogenen Raumstrukturen. Thesis, StuttgartHohenheim, 95 pp.

GARRISON R.W. 1978: A mark-recapture study of imaginal Enallagma cyathigerum (Charpentier) and Argia vivida Hagen (Zygoptera: Coenagrionidae). Odonatologica 7: 223-236.

Higashi K. \& Ueda T. 1982: Territoriality and movement pattern in a population of Calopteryx cornelia. Odonatologica 11: $129-138$.

JefFries M., EAles H.T. \& Storey G. 2005: Distribution and habitat of the Blanded Demoiselle Calopteryx splendens (Harris) in Northumberland. J. Br. Dragonfly Soc. 21: 1-7.

JoHnson C.G. 1969: Migration and Dispersal of Insects by Flight. Methuen, London, 763 pp.

KiAUTA B. 1963: A note on an unusual habitat of Calopteryx virgo L. (Calopterygidae). Tombo 6: 25-26.

Madsen B.L., Bengston J. \& Butz I. 1973: Observations on upstream migrations by imagines of some Plecoptera and Ephemeroptera. Limnol. Oceanogr. 18: 678-681.

Michiels N.K. \& Dhondt A.A. 1991: Characteristics of dispersal in sexually mature dragonflies. Ecol. Entomol. 16: 449-459.

Mitchell R. 1962: Storm-induced dispersal in the damselfly Ischnura verticalis. Am. Midl. Nat. 68: 199-202.

Mearns B. \& Mearns R. 2005: Dragonfly News 47. p. 21.

MÜLLER K. 1982: The colonization cycle of freshwater insects. Oecologia 52: 202-207.

PAJUNEN V.I. 1966: Aggressive behaviour and territoriality in a population of Calopteryx virgo L. (Odonata: Calopterygidae). Ann. Zool. Fenn. 3: 201-214.

Peckarsky B.L., Taylor B.W. \& Caudill C.C. 2000: Hydrologic and behavioural constraints on oviposition of stream insects: implications for adult dispersal. Oecologia 125: 186-200.

Rankin M.A. \& Burchsted J.C.A. 1992: The cost of migration in insects. Annu. Rev. Entomol. 37: 533-559.

Rudd N.T. \& McEvoy P.B. 1996: Local dispersal by the cinnabar moth Tyria jacobaeae. Ecol. Appl. 6: 285-297.

Schutte G., Reich M. \& Plachter H. 1997: Mobility of the rheobiont damselfly Calopteryx splendens (Harris) in fragmented habitats (Zygoptera: Calopterygidae). Odonatologica 26: $317-327$.

SteTtMer C. 1996: Colonisation and dispersal patterns of banded (Calopteryx splendens) and beautiful (C. virgo) (Odonata: Calopterygidae) in south-east German streams. Eur. J. Entomol. 93: 579-593.

Svensson B.W. 1974: Population movements of adult Trichoptera at a South Swedish stream. Oikos 25: 157-175.

SwITZER P.V. 1997a: Factors affecting site fidelity in a territorial animal, Perithemis tenera. Anim. Behav. 53: 865-877.

Switzer P.V. 1997b: Past reproductive success affects future habitat selection. Behav. Ecol. Sociobiol. 40: 307-312.

WAAGE J.K. 1972: Longevity and mobility of adult Calopteryx maculata (Beauvois, 1805) (Zygoptera: Calopterygidae). Odonatologica 1: 155-162.

WARD L. \& MiLl P.J. 2004: Distribution of Calopteryx splendens (Harris) in northern England: an example of range expansion? J. Br. Dragonfly Soc. 20: 61-69.

WARD L. \& MILL P.J. 2005: Habitat factors affecting the presence of adult Calopteryx splendens (Odonata: Zygoptera). Eur. J. Entomol. 102: 47-51.

ZAHNER R. 1960: Über die Bindung der mitteleuropäischen Calopteryx-arten (Odonata, Zygoptera) an den Lebensraum des strömenden Wassers. I. Der Anteil der larven an der Biotopbindung. Int. Revue Ges. Hydrobiol. Hydrogr. 44: 51-130.

Received July 8, 2006; revised and accepted November 16, 2006 